\title{
Artur Mękarski
}

https://orcid.org/0000-0002-4856-4521

Uniwersytet Śląski

\section{Ideologiczno-metodologiczne meandry Rozważań o wojnie domowej Pawła Jasienicy. Uwagi o dziele i jego recepcji}

Zarys treści: Przedmiotem artykułu są Rozważania o wojnie domowej, ostatnia książka Pawła Jasienicy, eseisty i uznanego pisarza historycznego, znanego głównie z książek o historii Polski. Artykuł proponuje analizę książki i jej recepcji. Realizując pierwsze zadanie, autor skupia uwagę na krytyce ideologii komunistycznej, którą Jasienica w nieco zawoalowany sposób włączył do opisu głównego przedmiotu swej ostatniej książki - powstania w Wandei w $1793 \mathrm{r}$. W artykule wykazano, że Jasienica wykorzystał opis jednego z epizodów rewolucji francuskiej do krytyki systemu politycznego PRL, opowiadając się, należy dodać, za jego zastąpieniem przez demokrację liberalną. Analiza ukazuje także, że recepcja dzieła Jasienicy była w istotnym stopniu zapośredniczona przez preferencje ideologiczne recenzentów.

The content outline: This article deals with Rozważania o wojnie domowej (Reflections on the Civil War), the last book by Pawel Jasienica, an essayist and acclaimed history writer known mainly for his books on the history of Poland. The article offers analysis of both the work and its reception. In executing the first task, the author focuses on extracting the critique of the communist ideology which Jasienica included, in some veiled way, in his account of the main topic to which his last book is devoted - the Vendée rebellion of 1793. In the article Jasienica is shown to have used his account of one of the episodes of the French revolution to criticise the PRL's political system, arguing, one should add, in favour of replacing it with liberal democracy. Analysis also shows that the reception of Jasienica's work was significantly mediated by the ideological preferences of its reviewers.

Słowa kluczowe: Paweł Jasienica, historiografia, powstanie w Wandei, rewolucja francuska, ideologia, komunizm, PRL

Keywords: Paweł Jasienica, historiography, the Vendée Rebellion, the French Revolution, ideology, communism, the Polish People's Republic 
„Pamiętasz fenomenalne Rozważania o wojnie domowej Jasienicy? Kiedyś, na jakimś seminarium, posprzeczałem się z kolegami - historykami, którzy do tego tekstu podeszli w taki sposób rygorystycznie naukowy, co jest w ogóle od rzeczy, bo tekst nie był o tym [tj. nie był o wojnie w Wandei - A.M]. Tekst był o wojnie domowej i o reformie rolnej w Polsce po wojnie i o nacjonalizacji”'. Tak oto Stefan Meller, kilkanaście lat po upadku komunizmu, charakteryzował zakres zagadnień, do których, jak mniemał, odnosiła się ostatnia praca Pawła Jasienicy. Ta bardzo śmiała identyfikacja tematu Rozważań szła, zauważmy, w parze z odwróceniem norm zazwyczaj rządzących oceną prac historycznych. Meller chwalił książkę Jasienicy, a jednocześnie konstatował jej wyraźnie ideologiczny charakter. A przecież zwykle krytykuje się praktykę wciągania historiografii w bieżące spory polityczno-ideologiczne. Oczywiście Meller przesadzał. Jego opinia pokazuje jednak, że Rozważania stały się przedmiotem kontrowersji, w której ściśle poznawcze cele, jakie stawia się studiom historycznym, ścierały się z ideowymi dylematami epoki PRL. Warto zatem przyjrzeć się bliżej zarówno samemu dziełu, jak i jego recepcji.

W odróżnieniu od poprzednich książek Jasienicy, koncentrujących się wyłącznie na dziejach Polski, Rozważania o wojnie domowej poświęcone zostały bratobójczym zmaganiom rewolucyjnej Francji z mieszkańcami zbuntowanej Wandei. Tekst Rozważań powstawał przy tym w okresie, w którym w prasie trwała nagonka na Jasienicę. Rozpowszechniane wówczas pomówienia były odwetem za sprzeciw, jaki pisarz wyraził na jednym z zebrań Związku Literatów Polskich wobec nałożonego przez władze zakazu wystawiania Dziadów i za obronę buntującej się przeciwko tej decyzji młodzieży ${ }^{2}$. Można tylko spekulować, czy i na ile specyficzne okoliczności powstania dzieła opowiadającego o wydarzeniach sprzed niemal 200 lat wpłynęły na stopień, w jakim zostało ono wykorzystane do krytyki panującego w Polsce ustroju społeczno-politycznego. Nie ulega bowiem wątpliwości, że niektóre spostrzeżenia Jasienicy, ważne dla wywodów dotyczących rebelii z 1793 r., w sposób całkowicie zamierzony odnosiły się również do powojennej Polski (co oczywiście nie uzasadniania twierdzenia, że książka była o reformie rolnej albo o nacjonalizacji w Polsce). Nie mniej wyjątkowe okazały się też okoliczności, w jakich pracę opublikowano. Jasienica pisał ją w czasie, gdy jego nazwisko objęte było zakazem publikacji. Z punktu widzenia władzy zakaz ten był zapewne szczególnie

${ }^{1}$ Świat według Mellera. Życie i historia. Ku wolności. Ze Stefanem Mellerem rozmawia Michał Komar, Warszawa 2008, s. 231.

2 Szerzej na ten temat: J. Lipski, Pisma polityczne, wybór i oprac. Ł. Garbal, Warszawa 2011, s. 97-110; A. Kierys, Polska Jasienicy. Biografia publicysty, Kraków 2015, s. 518-523; J. Eisler, Jasienica, „Po Prostu” 9 VIII 1990. 
uzasadniony w odniesieniu do dzieła zawierającego bardzo słabo zawoalowaną krytykę ideologii leżącej u podstaw ustroju Polski Ludowej. Nic więc dziwnego, że na oficjalne wydanie Rozważań trzeba było czekać aż do połowy lat 80 ., czyli do czasu, w którym kraj miał już za sobą doświadczenia związane z powstaniem „Solidarności”, a następnie z wprowadzeniem i wygaszeniem stanu wojennego ${ }^{3}$. Nie było to bez znaczenia dla recepcji dzieła.

Pamiętając o szczególnych cechach dzieła i jego historii, nie sposób jednocześnie nie zauważyć, że pozostawało ono w zgodzie z ogólnym charakterem twórczości historycznej Pawła Jasienicy. Kolejne prace pisarza, utrzymane w konwencji quasi-reporterskiej gawędy, celowały w ustalaniu ogólnych prawideł rządzących światem polityki ${ }^{4}$. Zdradzały dążenie autora do uchwycenia reguł skutecznego kierowania nawą państwową. Piętnowały odstępstwa od norm gwarantujących historyczny sukces - słowem, analizowały złożone mechanizmy życia politycznego. Zawierały również wyraźne przesłanie ideowe. Nie ulega chyba wątpliwości, że rewolucja francuska stanowiła doskonałe pole do tego typu refleksji. Jeśli cieszące się dużą popularnością książki Jasienicy były chętnie recenzowane zarówno przez publicystów, jak i zawodowych, nierzadko bardzo wybitnych, historyków, to ze zrozumiałych względów również Rozważania o wojnie domowej przyciągnęły uwagę szerokiego grona komentatorów. Podejmowały wszak temat o niewątpliwie dużym ciężarze gatunkowym. W powszechnej opinii rewolucja francuska wywarła przecież przemożny wpływ na dzieje Europy. Wyznaczyła wzory przyszłych systemów politycznych i ustrojowych. Stała się zarzewiem głównych nurtów ideologicznych współczesności. Stanowiła również istotne ogniwo stalinowsko-marksistowskiej historiozofii. Poświęcona jej praca niejako naturalnie prowokowała do uwag dotykających fundamentalnych kwestii natury historycznej, metodologicznej i światopoglądowej.

W pierwszej części poniższych analiz omawiam treść pracy Jasienicy, wydobywając z niej krytykę komunistycznej utopii, a więc zagadnienie ściśle związane z polską rzeczywistością polityczno-ustrojową. Druga cześć tekstu przedstawia recepcję pracy. W analizie uwag i komentarzy, jakie poświęcono Rozważaniom, najpierw omawiam te, które wskazywały na ich związek z peerelowską współczesnością, a następnie te, które odnosiły się do przedstawionego w nich obrazu wojny w Wandei.

${ }^{3}$ Rozważania pierwotnie opublikowano w drugim obiegu. W 1979 r. wydała je Niezależna Oficyna Wydawnicza NOW-a. Następnie, w 1983 r., ukazywały się w odcinkach w „Życiu Literackim”. W 1985 r. opublikowało je w całości Wydawnictwo Literackie.

${ }^{4}$ Poglądy Jasienicy na dzieje Polski omawiam w artykule Między mitem a polityczna racjonalnością. Myśl historyczna Pawła Jasienicy i jej recepcja w dobie Polski Ludowej, „Kwartalnik Historyczny" 2013, nr 1, s. 55-97. 


\section{II}

Zasadniczym przedmiotem Rozważań o wojnie domowej jest rebelia, jaką chłopi z Wandei wzniecili w marcu $1793 \mathrm{r}$. W skierowanym przeciwko młodej Republice wystąpieniu widział Jasienica przede wszystkim egzemplifikację oporu wobec prób przekształcenia życia mieszkańców według ideologicznych wzorów narzuconych przez rewolucyjne władze - wzorów gwałcących miejscowe przyzwyczajenia i tradycje. Opowieść o ludowej kontrrewolucji nabierała więc dlań znaczenia głównie w kontekście rozrachunku z samą rewolucją, czy też - by ująć rzecz precyzyjniej - z jej ideologicznymi wynaturzeniami. Powstanie w Wandei uważał Jasienica za symbol zerwania $z$ ideałami, w imię których, jak wierzył, Francuzi sięgnęli po broń w 1789 r. Interesowała go więc ciemna strona francuskiego przewrotu. Postanowił ją ukazać z perspektywy mieszkańców zbuntowanego regionu, identyfikując postawy i przekonania, które sprowadziły rewolucję na manowce i sprawiły, że przeistoczyła się $\mathrm{w}$ sprzeczne $\mathrm{z}$ wartościami oświecenia rządy terroru.

Lektura Rozważań nie pozostawia wątpliwości, że sympatie autora były po stronie zbuntowanej Wandei. Tłumacząc motywy, które kierowały zachowaniem powstańców, Jasienica podkreślał ich głębokie przywiązanie do tradycji, religii i monarchii. Przekonywał, że walczyli wyłącznie w obronie autentycznych, historycznie utrwalonych wartości. „Naprawdę pragnęli tylko zachować swą wiarę i żyć w spokoju”. System wartości wpływający na postawy i działania powstańców zmagających się z rewolucyjnym radykalizmem charakteryzował się nie tylko przywiązaniem do wiary i monarchii. Obejmował również aprobatę dla oświeceniowego programu reform. Wszak „uznali i przyjęli rewolucyjną zasadę równości wszystkich ludzi”5. Do oporu sprowokowały ich dopiero „zboczenia” rewolucji, wśród których autor Rozważań wymieniał m.in. mianowanie księży w drodze wyborów, w których uczestniczyć mogli również niekatolicy. Ostrze swojej krytyki kierował właśnie przeciwko owym „zboczeniom”, doceniając zarazem pozytywną rolę rewolucji i związanego z nią dziedzictwa. Jakże bowiem, pisał, „potępiać dzieło, które okazało się zdumiewająco płodne, podatne na ewolucję, przyswajalne w rozmaitych odmianach”. Wszystko to, dodawał, „czego nie potrzebuje się wstydzić wiek XX, wspierało się na francuskiej, rewolucyjnej podbudowie"6. Autor Rozważań nie wątpił przecież, że dzieje były domeną postępu. Odnosząc się do zmian, jakie na przestrzeni dziejów zaszły w zakresie społecznej akceptacji przemocy, podkreślał, że „sposoby postępowania, które w czasach wojny peloponeskiej stanowiły regułę, w naszej dobie historii zdarzają się już tylko jako wyjątek". Za owe wyjątki odpowiedzialna zaś była zwykle pokusa „wyregulowania raz na zawsze zgrzytliwego mechanizmu historii". We Francji stery rewolucji przejęli niepotrafiący się jej oprzeć

\footnotetext{
${ }^{5}$ P. Jasienica, Rozważania o wojnie domowej, Warszawa 2007, s. 11.

6 Tamże, s. 67.
} 
radykałowie. I to oni, a nie przywiązani do Kościoła i króla wandejscy chłopi, łączący wierność tradycji z postulatami przebudowy rzeczywistości politycznej w duchu oświecenia, sprzeniewierzyli się jego ideałom. Fanatyzmowi do pełnego triumfu wystarczyła tylko garstka oddanych aktywistów. Każdy, kto chciał uchodzić za lojalnego obywatela, musiał manifestować radość, że „oto nareszcie depce się i opluwa wszystko, co dotychczas kochał. Tak bowiem zamarzyło się nielicznej grupce mężów, powołanych przez Rozum... do wyprostowania historii”" . Z grona radykałów należało wyłączyć najwybitniejszych myślicieli oświecenia. Wolter czy Monteskiusz mieli niewiele wspólnego z niespełnionymi nienawistnikami, którzy, wypychając kraj z ram, jakie nadała mu konstytucja, pozbawili go zarazem szans na zdobycie pozycji lidera rozwoju społecznego w Europie. W rękach fanatyków idee wielkich filozofów zmieniały się w swoje przeciwieństwo. W konkluzjach do swoich rozważań Jasienica pisał:

\begin{abstract}
Jedyną prawdziwą koniecznością historyczną jest nieustanna naprawa stanu posiadania. Reformowanie nie może się nigdy skończyć, stanowi istotę tych programów, którym warto służyć. [...] W oczywisty sposób niezgodny z tym założeniem jest taki stan rzeczy, w którym nieliczna grupa osób w imię najszlachetniejszych wizji tworzy i skutecznie zagarnia na swój użytek przywilej rozkazywania sądom - pozostałe miliony ludzi tracą prawo do obrony. Należy rozstać się z przyjemnym złudzeniem, że nierówności majątkowe lub rozmaity stosunek do środków produkcji są jedynym źródłem niesprawiedliwości [podkr. A.M.].

[...] Nic niestety nie zabezpiecza ogółu przed działaczami politycznymi odrzucającymi zasadę podziału władz i nieustannej kontroli społecznej nad nimi. Tymczasem zaś znacznie starsze od Monteskiusza doświadczenie historii pozwala stwierdzić, że skoncentrowana i pozbawiona hamulca wszechwładza działa równie błogo i skutecznie, jak wypuszczone na swobodę zarazki tężca. Może nawet skuteczniej, skoro w XX stuleciu przyszło z musu do stworzenia pojęcia „zbrodni przeciw ludzkości”.

Książka ta mówiła o takich, co zbytnio miłując własne wizje, zdradzili program reformatorski, oraz o takich, co napiętnowani jako wstecznicy i zbrodniarze, byli mu właściwie wierni ${ }^{8}$.
\end{abstract}

Fraza łącząca niesprawiedliwość społeczną z kwestią dystrybucji środków produkcji stanowiła oczywiste nawiązanie do marksistowskiej wersji millenarystycznej utopii. Siłą rzeczy więc nie odnosiła się do wydarzeń, które pod koniec XVIII w. wstrząsnęły Francją i Europą. Refleksja nad dziejową rolą rozwoju środków produkcji oraz ich funkcją społeczną była integralnym składnikiem marksowskiej historiozofii wolności odwołującej się do pojęcia „samowzbogacającej się alienacji" . Odpowiednio zaawansowany poziom rozwoju wspomnianych środków produkcji decydował wszak o wkroczeniu w erę kapitalizmu, w której piekło alienacji osiągało swoje apogeum. Klasa robotnicza, jako pierwsza w dziejowym

7 Tamże, s. 63.

8 Tamże, s. 141-142.

9 W literaturze polskiej problem ten szeroko przedstawia A. Walicki, Marksizm i skok do królestwa wolności. Dzieje komunistycznej utopii, Warszawa 1996, s. 25-102. 
łańcuchu klas uciskanych, zyskiwała - właśnie z uwagi na niezwykłe natężenie wyalienowanych form życia - świadomość bolesnej rozbieżności między ludzką esencją a ludzką egzystencją. Fakt ów otwierał możliwość rewolucyjnego zniesienia prywatnej własności środków produkcji i przezwyciężenia alienacji w ustroju komunistycznym. $\mathrm{Z}$ tej perspektywy liberalizm, formalnie związany z krytyką feudalnych przywilejów oraz ideą powszechnej wolności, postrzegany był jako ideologia rozwijającego się kapitalizmu, maskująca zastąpienie wszelkich form zniewolenia bezpośredniego (takie jak zinstytucjonalizowane przywiązanie chłopów do ziemi) zniewoleniem narzuconym przez ślepe siły rynku. W przytoczonych wyżej uwagach Jasienica nawoływał do zerwania z komunistyczną utopią. W lekceważonych przez Marksa instytucjonalnych gwarancjach wolności widział prawdziwą wartość. Monopartyjną demokrację ludową bez wahania zastąpiłby opierającą się na podziale władzy liberalną demokracją.

Do finalistycznej historiozofii nawiązywał nie tylko wtręt dotyczący stosunków produkcji. To samo można powiedzieć o użytym przez Jasienicę w pierwszym zdaniu omawianego cytatu pojęciu „konieczności dziejowej”. Pojawia się ono zresztą w tekście Rozważań nie po raz pierwszy. W jednej z wcześniejszych partii książki Jasienica pisał:

\footnotetext{
Pojęcie konieczności dziejowej otwiera niekiedy drogę do groźnego absurdu. Ciągle czai się między ludźmi pokusa ostatecznego uporządkowania świata wynikła z przekonania, że dotychczasowa historia była właściwie omyłką. Niewiele krajów potrafiło się zabezpieczyć przed przywódcami nieżywiącymi wątpliwości, że prawidłowa historia zacznie się dopiero od nich.

Konieczność polega właściwie na nieustannej naprawie, bo porządku idealnego nigdy nie było, nie ma i nie będzie. Jedynym dorobkiem narodów jest to tylko, co wytworzyła ich własna, indywidualna i zbiorowa przeszłość. To ona dopracowała się w przeciągu wieków wartości bardzo nieraz względnych, lecz takich, którym ludzie gotowi są dochowywać wierności dozgonnej. Doświadczenie zaleca ostrożność. Nie tylko dlatego, że nadmiar reformatorskiej romantyki pobudza operowanych do oporu, też niekiedy absurdalnego. Dlatego również, że nieliczący się z niczym karczunek owych wartości upadla człowieka ${ }^{10}$.
}

Rewolucję z pojęciem „konieczności historycznej” powiązała myśl dziewiętnastowieczna. Wątpliwe, by rewolucjoniści posługiwali się nim w celu legitymizowania swoich działań. $Z$ pewnością można było im przypisać „pokusę ostatecznego uporządkowania świata” oraz przekonanie, „że właściwa historia rozpocznie się dopiero od nich". I choć formuły te można uznać za analityczne rozwinięcie pojęcia „konieczności historycznej” (wyzwolenie ludzkiej istoty gatunkowej zasługiwałoby na miano „ostatecznego uporządkowania świata”), to już twierdzenie odwrotne, sugerujące, że konieczność historyczna jest założona w pojęciu „ostatecznego uporządkowania świata" jest nieuzasadnione. Można żywić przekonanie, że oto uczestniczy się w budowie zupełnie nowej rzeczywistości, nie zakładając przy

10 P. Jasienica, Rozważania..., s. 46. 
tym, że doskonały kształt, jaki próbuje się jej nadać, jest tak czy inaczej z góry przesądzony, że jest konieczną kulminacją całego dotychczasowego biegu dziejów. Historiozoficzny determinizm nie kroczy jak cień za wiarą w lepsze i rozumniejsze jutro. Konieczność historyczna była reakcją na doświadczenie rewolucji. Nie była natomiast cechą mentalności jej twórców. Autor Rozważań popełnił anachronizm, posługując się dziejami osiemnastowiecznej Francji do dyskredytowania ideologicznych fundamentów ustroju Polski Ludowej. Bo przecież nie ulega wątpliwości, że w pełni zdawał sobie sprawę $\mathrm{z}$ asocjacji, jakie u polskiego czytelnika wywoła pojęcie „konieczności historycznej”, że zostanie ono natychmiast powiązane z komunistyczną utopią. Jest przy tym rzeczą niezwykle charakterystyczną, że w żaden sposób nie próbował charakteryzować ani finalnych form życia społecznego, ani etapów, które zdaniem rewolucjonistów nieuchronnie miałyby do nich prowadzić. Można zaryzykować twierdzenie, że brak ten wypełnić miała wyobraźnia czytelników, ukształtowana pod wpływem lektur przekonujących, że postęp w dziedzinie rozwoju środków produkcji determinował zmiany $\mathrm{w}$ sposobach gospodarowania oraz $\mathrm{w}$ ich prawnoustrojowej nadbudowie ${ }^{11}$. Wszelkie odniesienia, jakie czynił Jasienica do kategorii historiozoficznych miały nieodmiennie prezentystyczny posmak, przywoływały na myśl peerelowską teraźniejszość. Tak było niewątpliwie w przypadku konstatacji, że „dziwnie łatwo przychodzi ideologom odkrywanie rozmaitych praw historii" ${ }^{12}$.

Warto podkreślić, że Jasienica, który w Rozważaniach mierzył się z oceną dziedzictwa rewolucji i oświecenia, w swoich poprzednich dziełach dał się poznać jako zdecydowany zwolennik rozumu. Wspierając politykę opierającą się na racjonalnych przesłankach, sprzeciwiał się wszelkim próbom uzależniania jej od przekonań religijnych. Misję obrony katolicyzmu, w jaką jego zdaniem zaczęli wciągać kraj Jagiellonowie, uważał za jeden z głównych przejawów zerwania z tradycją dobrej szkoły politycznej Piastów. Piętnował zwrot Akademii Krakowskiej w stronę teologii. Uważał, że oznaczał on dostrajanie polskiej edukacji do „wymagań ogromnie zapóźnionych”. Te niekorzystne zmiany, jak podkreślał, następowały ponadto $\mathrm{w}$ dobie, $\mathrm{w}$ której „dawny teocentryzm trzymał się już tylko siłą bezwładu, kiełkowały zapowiedzi Renesansu”, a „Europa obracała się w stronę świecką"13. Podkreślał, że już w XV w. „ścieżka naszej historii zaczynała odbiegać od zwykłych europejskich dróg". Śmierć Władysława Jagiellończyka w 1444 r. uważał za zapowiedź „nieszczęść czekających Polskę na szlakach, które nie były jej własnymi drogami”. W unii brzeskiej z 1596 r. widział akt, „którego inaczej niż błędem nazwać nie można"14. Szczególnie krytycznie wypowiadał się

11 Zob. R. Stobiecki, Stalinowska mitologizacja idei postępu, w: Historia, mity, interpretacje, red. A. Barszczewska-Krupa, Łódź 1996, s. 139-147.

12 P. Jasienica, Rozważania..., s. 96.

13 Tenże, Polska Jagiellonów, Warszawa 1963, s. 96.

${ }^{14}$ Cyt. za: J. Tazbir, Wizja Polski Pawła Jasienicy, „Nowe Książki” 1984, nr 2, s. 3. 
też o kontrreformacji, której szermierze cofali Polskę "głębiej niż w tak zwane mroki średniowiecza” i „niszczyli u nas wielowiekowy dorobek”15.

\section{III}

Opublikowane w oficjalnym obiegu Rozważania spotkały się z dużym zainteresowaniem czytelników i komentatorów życia kulturalnego PRL. Znalazło ono swoje odzwierciedlenie w całkiem licznych, poświęconych książce recenzjach. Niektóre z nich ukazały się $\mathrm{w}$ pismach drugiego obiegu, a więc poza zasięgiem cenzury. W prasie pozostającej pod kontrolą władzy istniały niewątpliwie ograniczenia w zakresie eksplikacji i oceny ideowych aspektów dzieła. Nie znaczy to jednak, że recenzje i omówienia opublikowane pod nadzorem cenzury zupełnie uciekały od rozmaitych kwestii ideologicznych i światopoglądowych.

Podobieństwa między zgubnymi skutkami ślepego doktrynerstwa, jakie opanowało Francję w latach rewolucji oraz szkodami, na jakie narażały Polskę rządy komunistów, stawały się szczególnie wyraźne w świetle doświadczeń „Solidarności" (polscy robotnicy, podobnie jak niegdyś chłopi z Wandei, zbuntowali się przeciwko władzy powołanej rzekomo do obrony ich interesów). W takich analogicznych kategoriach odniósł się do Rozważań autor krótkiego omówienia opublikowanego w drugoobiegowym piśmie „Edukacja i Dialog”. „Lud walczy pisał - przeciw rewolucji - a więc »kontrrewolucja ludowa«? Znamy to skądś i to na świeżo”. W podsumowaniu zaś dodawał: „esej Jasienicy napisany został rok po marcu 1968. Mógłby i powinien ukazać się także po grudniu 1970, po czerwcu 1976, po sierpniu 1980, a po grudniu 1981 powinien być codziennie odczytywany przez radio..."16. Na historyczne analogie, jakie nasuwały się po lekturze Rozważań, zwracał uwagę również Włodzimierz Pawłowski, piszący od pseudonimem Piotr Gazda - dziennikarz, w latach 80. związany z miesięcznikiem „Literatura”. „Cudze doświadczenia - czytamy w obszernym tekście - nigdy nie są aż tak cudze, byśmy mogli pozwolić sobie na luksus nie oglądania się na nie”. W uwagach, jakie formułował, wyraźnie pobrzmiewała jednak nuta goryczy. Choć bowiem bieg zdarzeń jedynie potwierdzał przenikliwość Jasienicy, to przecież „przekleństwem jest posiadanie racji na zapas”, a „przy smutnych proroctwach niejeden wolałby być w błędzie" ${ }^{17}$. Odnotowawszy tę polsko-francuską zbieżność losu, recenzent jednocześnie podkreślał, że „dla literatury nie ma nic bardziej śmiercionośnego od natrętnie narzucającej się instrumentalizacji”. Myśl ta wyrażała, jak się zdaje, przekonanie, że Rozważania nie odzwierciedlały li tylko prostego użycia historii do forsowania określonej agendy polityczno-ideologicznej, ale że niosły przesłanie

15 Cyt. za: tamże, s. 3.

16 Książki dobre, choć ocenzurowane, „Edukacja i Dialog” 1986, nr 2, s. 47-48.

17 P. Gazda (właść. W. Pawłowski), Pochwała umiaru, „Metrum” 1988, nr 4, s. 43. 
bardziej uniwersalne. Pytania, które stawiał Jasienica i problemy, do których się odnosił, miały charakter ogólnoludzki, wykraczający poza parametry konkretnego czasu i miejsca. Chyba w takich ogólnych ramach mieścił się następujący komentarz Pawłowskiego:

Zdziwienie, iż oto ktoś i gdzieś żyje tak, jak nie żyje już nikt, jest rzeczą naturalną. Ale skąd
ta pogarda, pozwalająca nazywać go ślepcem, a jego kraj cuchnącą sadzawką zatrzymującą
pochód postępu? Skąd to zadufanie, nakazujące swoje uważać zawsze za lepsze, cudze za gorsze,
zezwalające na stosowanie wobec maluczkich i ciemnych każdej z metod, jeśli tylko doprowadza
ich do krainy przymusowego szczęścia? Nosiciele wyabsolutnionych racji bywają szczególnie
niebezpieczni. Zrozumienie prostej prawdy, że niektórym łatwiej jest przystać na ład niedo-
skonały, aniżeli godzić się na idealny chaos, leży praktycznie poza zasięgiem ich możliwości' ${ }^{18}$.

Kolejny tekst poświęcony Rozważaniom, który ukazał się w drugim obiegu, zatytułowany został Ostatnia ksiażka, ostatnie stowo ${ }^{19}$. Jego autor nie miał wątpliwości, że Jasienica podejmował dyskusję nad kwestiami, „które w równej mierze dotyczyły przeszłości, jak i teraźniejszości lat sześćdziesiątych” XX w. Z jednej strony refleksja historyczna pozwalała pisarzowi odnieść się krytycznie do czasów, w których żył, z drugiej zaś jego doświadczenia determinowały sposób, w jaki oceniał odległa przeszłość. Recenzent trafnie rozpoznawał sformułowaną w Rozważaniach krytykę ideologii komunistycznej. Identyfikował również fragmenty odnoszące się do udziału Jasienicy w bratobójczych starciach z lat 40. Ten ostatni wątek przedstawiał następująco:

Gdy Jasienica pisze „o wściekłej walce o utrzymanie władzy” czy „niszczeniu najcenniejszych substancji narodowych” znać tu echa jego biografii. Jasienica w czasie wojny był żołnierzem ZWZ, a następnie AK. Walczył w słynnym oddziale Łupaszki, który nie uznał nadchodzącej ze wschodu władzy. Historia wyznaczyła tym ludziom los pokonanych. W kontekście tych faktów fragmenty o gwałcie i śmierci, rozpaczy i desperacji stają się refleksem autentycznych przeżyć. Nabierają mocy, jako argumenty przeciwko jakiemukolwiek podporządkowaniu osoby ludzkiej doktrynie ${ }^{20}$.

W pismach drugiego obiegu Rozważania spotkały się z pozytywnym odbiorem. Opinie o dziele, eksponujące jego odniesienia do współczesności, pozbawione były akcentów krytycznych (z jednym wyjątkiem, do którego przyjdzie jeszcze wrócić). Nawiązania do współczesności uważano za zaletę pracy i świadectwo wyobraźni historycznej autora. Nie rozważano przy tym kwestii, czy ów swoisty prezentyzm nie wpływał ujemnie na sposób, w jaki Jasienica prezentował dzieje rewolucji francuskiej. Odmiennie przedstawiała się recepcja pracy w czasopismach oficjalnego obiegu.

18 Tamże, s. 46.

19 Ostatnia książka, ostatnie słowo, „Kierunek” 1986, nr 1, s. 15-18.

20 Tamże, s. 17. 
„Interesujące i stronnicze” - w taki sposób w recenzji, która ukazała się na łamach „Miesięcznika Literackiego”, określił Rozważania teoretyk literatury Bogdan Owczarek $^{21}$. Stronniczość dzieła przejawiała się jego zdaniem w „doborze faktów, w charakterystyce bohaterów wydarzeń, w ocenie ich przekonań i motywów”. Owczarek podkreślał, że Jasienica ukazywał przede wszystkim negatywne cechy przywódców rewolucji, takie jak „skłonność do gromadzenia nieograniczonej władzy”, „dogmatyzm i doktrynerstwo otępiające umysł i wolę sprzeciwu” oraz manię „uszczęśliwiania swych bliźnich za wszelką cenę”. Brak obiektywizmu miał swoje źródła w ideologii nowoczesnego neokonserwatyzmu, z którym Owczarek łączył Rozważania, a który, jak twierdził, rozwinął się w reakcji na „radykalne ruchy studenckie i popularność marksizmu w latach sześćdziesiątych w Stanach Zjednoczonych i Europie Zachodniej”. Głosząc hasła „godności jednostki” oraz „Zachowania ogólnoludzkiej kultury”, inspirował on wielu intelektualistów katolickich w Polsce, w tym Jasienicę. Te neokonserwatywne afiliacje czyniły z Rozważań „wypowiedź ideologiczną”. W tym też zresztą do pewnego stopnia tkwiła ich wartość. Prezentowały bowiem "potrzebny krytycyzm wobec schematu, wobec łatwej i przyjemnej interpretacji rewolucji”, zakreślając zarazem ,jej inną perspektywę, z której widać niewidoczne jej strony i niebezpieczeństwa"22.

Z kolei o „pułapce tendencyjności”, w jaką miał wpaść Jasienica, pisał na łamach „Życia Warszawy” Kazimierz Koźniewski, pisarz, dziennikarz, znajomy autora, a zarazem... współpracownik Służby Bezpieczeństwa. Ponieważ praca miała „Z całą premedytacją... służyć polemikom teraźniejszości”, było czymś zupełnie zrozumiałym, że obraz przeszłości, jaki się z niej wyłaniał, był tendencyjny i zniekształcony. „Dla nikogo nie może ulegać wątpliwości”, przekonywał Koźniewski, że „pisząc o Wandei i Rewolucji Francuskiej Jasienica pisał o formowaniu się socjalistycznej Polski Ludowej”, a także „o sobie samym”23. Publicysta „Życia Warszawy” wskazywał na paradoksalną jego zdaniem relację między zmieniającymi się zapatrywaniami pisarza na rzeczywistość polityczną w kraju a polityczną wymową jego dzieł. Jasienica, pisał Koźniewski, „to zbliżał się do partii i państwa ludowego w pierwszej połowie lat pięćdziesiątych, to gwałtownie oddalał w latach sześćdziesiątych". Tej rosnącej dezaprobacie, z jaką traktował komunistyczną władzę, towarzyszyła publikacja kolejnych dzieł, w których „popularyzował bardzo laickie, bardzo racjonalistyczne, bardzo rozumne, zbliżone do marksistowskich historyków choć nie marksistowskie poglądy na dzieje Polski”. Z historiograficznego punktu widzenia charakterystyka ta jest tylko w części uzasadniona. Niewątpliwie druzgocąca krytyka unii z Litwą połączona z gloryfikacją Polski Piastów były zgodne z linią polityki historycznej komunistycznych władz. Ujęcie takie charakteryzowało

${ }_{21}$ B. Owczarek, Rozważania o kontrrewolucji, przemocy i doktrynerstwie, rec.: P. Jasienica, Rozważania o wojnie domowej, „Miesięcznik Literacki” 1987, nr 4, s. 156-157.

22 Tamże, s. 157.

${ }^{23}$ K. Koźniewski, Różnica zdań, „Życie Warszawy” 7-8 XII 1985, s. 4. 
jednak tylko pierwsze dwie części historycznej trylogii. W tomach poświęconych Rzeczypospolitej Obojga Narodów krytyka unii ustapiła retrospektywnej akceptacji związku obu państw ${ }^{24}$. Przede wszystkim jednak Jasienica podkreślał, że relacje między tworzącymi Rzeczpospolitą partnerami odzwierciedlały fundamentalne cywilizacyjne różnice dzielące Wschód i Zachód ${ }^{25}$. Teoria formacji, jak wiemy, sprowadzała dzieje Polski i Rosji do wspólnego historiozoficznego mianownika. $\mathrm{W}$ jej ramach oba państwa realizowały ten sam scenariusz rozwoju historycznego. Antyteza Wschodu i Zachodu, do której odwoływał się Jasienica, rozsadzała stalinowsko-marksistowski schemat legitymizujący sojusz ze Związkiem Radzieckim oraz budowę socjalizmu w Polsce Ludowej. W tym właśnie punkcie Jasienica zasłużył sobie na miano historiograficznego dysydenta.

W swoim tekście Koźniewski sugerował, że praca Jasienicy powinna się była ukazać razem z jej niezwykle krytyczną recenzją autorstwa Jana Baszkiewicza (analizuję ją szczegółowo w dalszej części artykułu). „Wydanie pod jedną okładką obu tekstów $[\ldots]$ byłoby $[. .$.$] lekcją twórczego myślenia historycznego poprzez$ polemikę, poprzez różnice zdań" ${ }^{26}$. Do takiego rozwiązania miało się ponoć skłaniać Wydawnictwo Literackie, które pracę wydało. Pomysł ten jednak, czytamy, nie zyskał akceptacji wdowy po Jasienicy.

Odrzucił go również Stefan Meller, który omówił Rozważania w katolickim „Znaku”27. Ten ostatni zaznaczył zarazem, że wydawnictwo mogło się było pokusić o posłowie, wskazujące na „,rzeczywiste kłopoty z lekturą tekstu”. Zdaniem Mellera Jasienica nie napisał rozprawy historycznej, gdyż nie konfrontował ze sobą różnych opinii. Także historiozofia nie była tą dziedziną, z którą należałoby łączyć Rozważania. Ich autor nie rozpatrywał bowiem "na szerszym tle analogicznych wątków". Po wyeliminowaniu różnych, nasuwających się możliwości gatunkowej klasyfikacji omawianego dzieła recenzent stwierdzał, że Jasienica zaprezentował „piękny esej o moralności, korzystający z historycznej faktografii” oraz „porywające rozważania o miłości do tradycji i nienawiści do jej burzycieli"28. Istota tych

${ }^{24}$ Piszę o tym szerzej w artykule Między mitem a polityczną racjonalnością...

25 Nawiązując do degeneracji ustrojowej Rzeczypospolitej w XVIII w., Jasienica pisał np.: „Polskie swobody stanowe przeszczepione zostały na grunt litewski poniekąd sztucznie, zarządzeniami monarchów, nie były w Wielkim Księstwie wynikiem ewolucji stosunków miejscowych. Mariaż zaawansowanego importu z prymitywnym podglebiem zrodził zjawiska monstrualne. Te same zasady, które na Zachód od Bugu stworzyły demokrację szlachecką, na wschód od niego pomogły wyrosnąć niebywale groźnej oligarchii”; tenże, Rzeczpospolita Obojga Narodów, t. 3: Dzieje agonii, Warszawa 1972, s. 75.

${ }^{26}$ K. Koźniewski, Różnica zdań..., s. 4.

27 S. Meller, Rozważania o „Rozważaniach o wojnie domowej”, „Znak” 1986, nr 6, s. 128-137.

${ }^{28}$ Meller rozwijał myśl związaną z próbą uchwycenia istoty dzieła Jasienicy. Jego dalsze uwagi zostały jednak usunięte przez cenzurę. Po sformułowaniu „rozważania o miłości do tradycji i nienawiści do jej burzycieli” czytelnik napotyka taki oto fragment: „[----] [Ustawa z dnia 31 VII 1981. O kontroli publikacji i widowisk, art. 2 pkt 6 (Dz. U. nr 20 poz. 99, zm.: 1983 Dz. U. nr 44 poz. 204)]"; tamże, s. 130. 
rozważań zaś sprowadzała się, zdaniem recenzenta, do przedstawienia konfliktu „między bezwzględną, uzbrojoną władzą, sfanatyzowaną i nietolerancyjną emanacją zdeformowanej myśli oświeceniowej, a zrewoltowaną w poczuciu bezradnej wściekłości wsią, zdradzoną przez rewolucję, a do tego zmuszaną do przyjmowania obcych sobie wzorów z jednoczesnym obowiązkiem deklarowania pozytywnych uczuć wobec prześladowców”29. W opisie „niezawinionego cierpienia biedaków, walczących o zachowanie tożsamości” dostrzegał Meller „wyraźne przesłanie religijne”. W obliczu nietypowego charakteru pracy „wstępowanie w szranki historyczne" uważał za bezcelowe, stwierdzając zarazem, że bardziej stosowna będzie „próba eksplikacji problemu, poprowadzona jakby obok tekstu Jasienicy”30. Wywody Mellera były oczywiście ważnym głosem w dyskusji wokół Rozważań i nie można ich pominąć $w$ niniejszej analizie. Zawierały one merytoryczną kontrpropozycję wobec obrazu rewolucji i insurekcji w Wandei, jaki w swojej książce stworzył Jasienica.

Rozterek związanych z charakterem Rozważań nie miał za to Jan Baszkiewicz, którego recenzja, zatytułowana Mitologia Wandei, ukazała się w „Polityce”31. Warto wspomnieć, że obaj recenzenci byli specjalistami od dziejów Francji i współautorami monumentalnego dzieła Rewolucja francuska 1789-1794. Społeczeństwo obywatelskie. W krytyce Rozważań odwoływali się do prac realizujących założenia nowoczesnej, nieklasycznej historiografii. Uwagi, jakie formułowali, wiązały się więc nie tylko z rzeczową, ale także $\mathrm{z}$ metodologiczną kontrpropozycją wobec eseju Jasienicy. Tradycyjnie zatem dyskusja nad pisarstwem historycznym autora Polski Piastów zyskiwała swój szczególny, metodologiczny wymiar. Baszkiewicz wskazywał, że już w latach 60 . powstały niezwykle ważne prace podejmujące temat powstania w Wandei, których Jasienica w ogóle nie wykorzystał, a które zdaniem recenzenta wniosły ogromny wkład w zrozumienie fenomenu chłopskiej insurekcji. Miejsko-wiejski antagonizm szczególnie przenikliwie ukazać miał w pracy o chłopach zachodniej Francji Paul Bois ${ }^{32}$. „Finezyjną analizę” specyficznie wandejskiej sociabilité przedstawił Marcel Faucheux ${ }^{33}$. Z kolei struktury społeczne i ich związek z kontrrewolucją opisał w swojej monografii amerykański badacz Charles Tilly ${ }^{34}$. Faucheux i Tilly, wskazywał Baszkiewicz, posługiwali się „inteligentnie statystykami, a nie uprzedzeniami i intuicjami”. Recenzent nie

29 Tamże.

30 Tamże.

31 J. Baszkiewicz, Mitologia Wandei, „Polityka” 1983, nr 44, s. 1, 10-14.

32 P. Bois, Paysans de L'Ouest, Paris 1971.

${ }_{33}$ Zob. M. Faucheux, L'Insurrection vendéenne de 1793. Aspects économiques et sociaux, Paris 1964.

${ }^{34}$ Ch. Tilly, The Vendée, Harvard 1976. Warto wspomnieć, że w 1967 r. ukazał się w „Kwartalniku Historycznym" większy tekst rekapitulujący najnowsze wówczas ustalenia historiografii w odniesieniu do kwestii Wandei; S. Salmonowicz, Wandea. Anatomia ludowej kontrrewolucji, „Kwartalnik Historyczny” 1967, nr 4, s. 945-962. 
podał przykładów „inteligentnego posługiwania się statystykami”. Można się jednak domyślać, że chodziło tu o takie wykorzystanie danych statystycznych, które uważa się - by użyć tu nomenklatury Jerzego Topolskiego - za oznakę zjawiska, o którym na ich podstawie pośrednio się wnioskuje. Przykładowo, badając statystyki dotyczące małżeństw zawieranych na terenie południowego Anjou, Tilly próbował określić zasięg geograficzny różnych relacji społecznych, w jakie wchodzili mieszkańcy zbuntowanego regionu. Amerykański historyk argumentował bowiem, że „the greater the tendency to local endogamy, the more likely it is that other social relations are highly localized"35. Esej Jasienicy zupełnie pomijał też procesy długiego trwania, które „przygotowywały eksplozję". Baszkiewicz konkludował więc, że „interpretacja Jasienicy prezentuje się anachronicznie" ${ }^{36}$. Ciekawe, że obaj historycy powstrzymali się od bliższego streszczania poglądów swoich zachodnich kolegów. Skupili się w zasadzie na konstatacji, że przywoływane przez nich prace pozwoliły powiązać wybuch powstania $\mathrm{z}$ konfliktem, stanowiącym specyfikę zbuntowanego regionu, między miastem i wsią ( $\mathrm{z}$ miast płynęły różne nienawistne zarządzenia, mieszczanie mieli monopol na stanowiska $\mathrm{w}$ administracji, $\mathrm{z}$ miast przysyłano poborców podatkowych oraz różne oddziałki dokonujące rekwizycji koni i żywności, mieszczanie kupowali dobra narodowe skonfiskowane przez rewolucję itp.). W tym kontekście Meller pisał więc, że „Wandea była przede wszystkim antymieszczańską rewolucją chłopską. Przywdziała zaś kostium monarchistyczno-religijny, bo takim tylko mogła dysponować"37. Myśl tę powtórzył w wydanej w $1991 \mathrm{r}$. pracy Pożegnanie z rewolucją. Pisał w niej: „Na plan pierwszy wysunąłbym nie kontrrewolucyjność, wynikającą z monarchizmu i klerykalizmu Wandei, jak to czyni w zasadzie P. Jasienica, lecz przede wszystkim antagonizm wieś-miasto"38 (jak widzimy, w powyższej wypowiedzi Jasienica potraktowany został jako autor pracy o Wandei, nie zaś o nacjonalizacji w Polsce). Przejawem wspomnianego konfliktu, na który wskazywali recenzenci, było rozgoryczenie chłopów związane $\mathrm{z}$ całkowitym skupieniem $\mathrm{w}$ rękach burżuazji ziem odebranych podczas rewolucji Kościołowi. Nieco pogłębioną argumentację, opierającą się na badaniach Bois, Tilly’ego i Faucheux, przedstawił za to Baszkiewicz we wspomnianej wyżej pracy o społeczeństwie francuskim w dobie rewolucji. Czytamy w niej m.in.:

\footnotetext{
Wandejski chłop żył w swej izolacji. Jego kraj, pocięty na zamknięte pola, bocage, zacieśniał jego widnokrąg, i to nie tylko w sensie fizycznym. Sprzyjał jego skłonnościom do indywidualizmu, egoizmu, uporu, polegania na własnych siłach. Miasto było dlań obce. Żyjąc w gospodarce na poły zamkniętej, chłop rzadko pojawia się na miejskim rynku. Gdy zaś się tam już pokazywał, jego uczucie obcości zabarwiało się zawiścią. Była już mowa o kontraście między zaniedbaną
}

${ }^{35}$ Ch. Tilly, dz. cyt., s. 89.

${ }^{36}$ J. Baszkiewicz, Mitologia Wandei..., s. 13.

37 S. Meller, Rozważania..., s. 136.

38 Tenże, Pożegnanie z rewolucją, Chotomów 1991, s. 143. 
wandejską wsią i zamożnymi miastami. W dodatku żarliwy katolik ze wsi wie, że miasto jest gniazdem niedowiarków i protestantów, że bourgeois często nie chodzi wcale na mszę lub uczęszcza na nabożeństwa heretyckie ${ }^{39}$.

Do powyższych czynników dochodziły m.in. niewielka liczba klasztorów, „które gdzie indziej prowokowały często chłopski antyklerykalizm", a także wspomniana już zdecydowanie przez chłopa przegrana konkurencja o ziemię. Gorycz płynąca $\mathrm{z}$ tej porażki, jak wskazywał Baszkiewicz, nie była tak boleśnie przeżywana w sąsiednich uboższych rejonach, w których chłopi byli zbyt słabi ekonomicznie, by robić sobie większe nadzieje na kupno ziemi. W Wandei było inaczej. „Chłop wandejski, uparty i mimo wszystko nie najbiedniejszy, przegrywając licytację przeżuwał długo i boleśnie swą klęskę" 40 .

Wskazując na znaczenie rekonstrukcji procesów długiego trwania, na możliwości, jakie dawało historykom „inteligentne posługiwanie się statystykami”, na potrzebę rekonstruowania struktur społecznych, ekonomicznych itd., Baszkiewicz przywoływał model historiografii, z którego - do czego żaden z recenzentów się nie odniósł - Jasienica programowo rezygnował. W Rozważaniach znajdujemy bowiem taki oto fragment:

Szkic literacki nie ma prawa, autor jego nie powinien też żywić zamiaru zastępowania historii naukowej. Dzięki niej przyszłość pozna strukturę kraju, ekonomiczną, społeczną, prawną i kulturalną sytuację jego mieszkańców. Całokształt tych stosunków wywierał wpływ na postępowanie ludzi, lecz literatowi wolno już teraz interesować się naturą bodźców oddziaływających na nich bezpośrednio. Żadna przecież z działających osób nie ogarniała myślą całej, niezmiernie skomplikowanej problematyki regionu nawet, już nie mówiąc o całym państwie. Zgłębi ją dopiero współczesny nam historyk, postępujący z rozwagą, starający się nie stracić z oczu żadnego szczegółu. Rezultat jego pracy nosić będzie charakter spokojnego komunikatu, powstaniec zaś wandejski działał pod wpływem emocji. Wielorako uwarunkowane bodźce docierały do niego w postaci wstrząsów psychicznych i moralnych. Obrażone uczucie pchało do obrony umiłowań, do walki, zemsty i ofiary.

Powołaniem literatury jest przenikanie tej właśnie strefy faktów, jak najbardziej realnych ${ }^{41}$.

Poszukując epistemologicznie bezpiecznej przystani, autor Polski Piastów próbował zatem oddzielić obszar zainteresowań parającego się historią literata od domeny pozostającej w jego mniemaniu w wyłącznej gestii historii naukowej. Ten klarownie zarysowany podział pracy odnosił się do stosowanego niekiedy rozróżnienia między obiektywną a subiektywną stroną procesu dziejowego, czyli między zbiorowymi (i przynajmniej przez większą część dotychczasowej historii człowieka nieuświadamianymi) rezultatami ludzkich działań, składającymi się na względnie trwałe, strukturalne składniki rzeczywistości z jednej strony,

39 J. Baszkiewicz, S. Meller, Rewolucja francuska 1789-1794. Społeczeństwo obywatelskie, Warszawa 1983, s. 276.

40 Tamże, s. 277.

${ }^{41}$ P. Jasienica, Rozważania..., s. 52. 
a świadomymi działaniami ludzi z drugiej. Można zrozumieć, że bardziej od bezosobowych procesów, do rekonstrukcji których powołana była właśnie naukowa historiografia, Jasienicę jako literata interesowały świadome zmagania ludzi z losem.

Wskazana dystynkcja nie była zwykłym, poczynionym ad hoc wybiegiem uzasadniającym pominięcie prac, które komplikowałyby ideowy przekaz Rozważań - krytykę ideologii i pochwalę społeczeństwa broniącego swojej podmiotowości i swoich tradycji. Jasienica odnosił się do tego rozróżnienia na długo przed podjęciem tematu Wandei, a czynił to oczywiście z pełną świadomością jego marksistowskich konotacji. W wywiadzie udzielonym „Polityce” w 1960 r. określał się mianem pisarza historycznego, natomiast na pytanie dotyczące konieczności historycznych odpowiadał, że „konieczność historyczna - to po prostu główny problem do rozwiązania $\mathrm{w}$ danej epoce. Ale samo rozwiązanie może wypaść dobrze albo źle"42. W wydanej dwa lata później pracy Tylko o historii przyznawał, że „główny nurt historii kształtują zjawiska niezależne od woli działających osób, a nawet pokoleń". Zarazem jednak wskazywał, że „w szerokich ramach, stworzonych przez konieczności wynikłe z ogólnego rozwoju warunków ludzkiego bytowania, jest dość miejsca na postanowienia i czyny rozstrzygające o szczęściu i nędzy, nawet o życiu i śmierci całych narodów"33. Należy podkreślić, że konieczność historyczna, która pojawia się w przytoczonym wyżej cytacie, odnosi się właśnie do istniejących, historycznie utrwalonych stanów rzeczy i nie wiąże się z żadnym rodzajem historiozoficznej profecji. Nie należy więc utożsamiać jej z pojęciem „konieczności dziejowej”, które Jasienica krytykował w eseju o wojnie domowej. Sens przytoczonych wyżej uwag wiązał się z dążeniem do zrzucenia krępującego gorsetu twardej wersji marksizmu i miał na celu ochronę autonomii działań podejmowanych $\mathrm{w}$ sferze politycznej ${ }^{44}$. Jasienica rozwijał swoje poglądy w opozycji do teorii traktującej rzeczywistość polityczną jako epifenomen relacji klasowych zdeterminowanych poziomem rozwoju środków produkcji. Teoria ta nie tylko radykalnie zawężała pole interpretacji działań postaci historycznych, ale również nierzadko, zwłaszcza w praktyce historiograficznej lat 50., wykorzystywana była do realizacji politycznych celów komunistycznego reżimu. Ten ostatni wątek, warto wspomnieć, był szczególnie intensywnie eksploatowany na uchodźstwie ${ }^{45}$. Jeden $z$ emigracyjnych autorów podkreślał np., że przedstawiony przez Bronisława Baczkę w pracy o Towarzystwie Demokratycznym obraz Ludwika

42 O historii po heretycku. Z Pawłem Jasienica w imieniu „Polityki” rozmawia Krystyna Nastulanka, „Polityka” 1960, nr 48, s. 7.

${ }^{43}$ P. Jasienica, Tylko o historii, Warszawa 1962, s. 92.

${ }^{44}$ W tym kontekście Jasienica pisał np.: „Powiedzieć, że zgodna współpraca Jagiełły, Witolda i Skirgiełly doprowadziła do prawdziwego zjednoczenia Litwy - to haniebny personalizm. Przemilczeć świadomą celu pracę tych polityków a powołać się na »tendencję" - oto właściwy sposób postępowania"; tenże, Polska anarchia, Warszawa 1988, s. 46.

${ }^{45}$ Zob. A. Mękarski, Między historiozofia a polityką. Historiografia Polski Ludowej w opiniach i komentarzach historyków i publicystów emigracyjnych 1945-1989, Warszawa 2011. 
Mierosławskiego jako reakcyjnego reprezentanta prawicy TDP był zupełnie nieuzasadniony ${ }^{46}$. Towarzystwo było bowiem organizacją ideologicznie spójną, sam Mierosławski zaś, domagając się uwłaszczenia chłopów bez odszkodowań, głosił bardzo radykalny program społeczny. Reakcyjną łatkę próbowano mu jednak przypiąć, gdyż szczególnie krytycznie odnosił się do Rosji i wspierał program odbudowy Rzeczypospolitej w granicach sprzed 1772 r. ${ }^{47}$

Jasienica zdawał sobie sprawę z kierunku rozwoju historiografii, z jej rosnącego zainteresowania obiektywną stroną procesu dziejowego. $\mathrm{W}$ tomach poświęconych Rzeczypospolitej Obojga Narodów do pewnego przynajmniej stopnia starał się uwzględniać wyniki badań nad dziejami społeczno-gospodarczymi. Powołując się na ustalenia „dzisiejszych ekonomistów”, wskazywał na kurczenie się rynku wewnętrznego, na związaną z tym pogarszającą się dolę chłopa, na spadek wartości pieniądza itd. ${ }^{48}$ Kryzys gospodarczy z pierwszej połowy XVII w. stawał się jednym z elementów wpływających na stopniową utratę politycznej mocy Rzeczypospolitej. Zarazem jednak dla Jasienicy, inaczej niż dla marksistów, to nie kryzys gospodarczy determinował kłopoty polityczne, lecz odwrotnie - to błędne decyzje polityczne sprowadzały na kraj kłopoty gospodarcze ${ }^{49}$. Można chyba zaryzykować tezę, że określone okoliczności historyczne liczyły się dlań jako przeszkoda, z którą należy się uporać. Odrzucał zaś marksistowskie przekonanie o tym, że kształtują one świadomość i że wpływają na sposób przedstawiania świata. Zauważmy, że twierdząc, iż konieczność historyczna to po prostu problem do rozwiązania w danej epoce, Jasienica radykalnie odwracał założenia marksizmu - szczególnie jego twardszych wersji. Formuła ta zakładała bowiem pełną autonomię świadomości wobec obiektywnej strony procesu dziejowego, czyli wobec utrwalonych struktur społecznych, ekonomicznych, mentalnych czy nawet geograficznych.

${ }^{4}$ B. Baczko, Poglądy społeczno-polityczne i filozoficzne Towarzystwa Demokratycznego Polskiego, Warszawa 1955.

47 J. Żmigrodzki, Sąd nad Mierosławskim, „Polemiki” 1966, nr 5, s. 57.

${ }^{48} \mathrm{Na}$ temat ewolucji, jaką w tym względzie przeszedł Jasienica, ciekawie pisał Aleksander Gieysztor we wspomnieniu o Jasienicy: „Większość historyków zawodowych myśli dziś także o historii innej, historii o dużym przebiegu, szerokim rytmie i oddechu, o procesach, choć schematyzm ich pojmowania wyrządził w minionych latach tyleż szkody w popularności nauki historycznej, co samym jej pracownikom. Myśli także o strukturach społecznych i psychicznych, o mentalności zbiorowej i indywidualnej, o dorobku własnym i o udziale tego dorobku w kulturze świata. Czyżby Jasienica pozostał na te wezwania nieczuły? Na pewno nie. Wystarczy porównać horyzont Polski Piastów z nabrzmiałym myślami różnorakimi tomem Srebrnego Wieku, aby uprzytomnić sobie odbytą w ciągu lat bez mała dziesięciu drogę Jasienicy - syntetyka i pisarza historyczno-politycznego. »Rozchodzenie się dróg władzy i Obojga Narodów Rzeczypospolitej « to już przykład analizy wielowarstwowej, w której pisarz i historyk dokonał sztuki niezwykle trudnej pisania dla ogółu Polaków i dla jego cząstki - fachowo przygotowanej i z obowiązku swego zawodu czujnej na historię ojczystą”; tenże, Paweł Jasienica. Historyk polski, „Tygodnik Powszechny” 1971, nr 34, s. 7.

49 P. Jasienica, Rzeczpospolita Obojga Narodów, t. 1: Srebrny Wiek, Warszawa 1967, s. 349-350. 
Przytoczoną wyżej próbę dystansowania się od wzorów historiografii naukowej należy niewątpliwie odczytywać w kontekście teoretycznych poglądów Jasienicy. Jeśli rezygnował $\mathrm{z}$ wglądu w badania nad obiektywną stroną procesu dziejowego, to przecież nie dlatego, że rola pisarza/eseisty, którą dla siebie rezerwował, niejako wymagała takiej rezygnacji, lecz dlatego, iż - jak widzieliśmy - nie sądził, by pociągła ona za sobą poważne szkody epistemologiczne. $W$ tym punkcie hołdował założeniom, z którymi modernistycznie nastawieni badacze zapewne by się nie zgodzili. Niewątpliwie działanie świadomości zmagającej się z oporem obiektywnych okoliczności historycznych stanowi „jak najbardziej realną strefę faktów". Jednak już radykalna heurystyczna separacja tych dwóch porządków, dokonana $\mathrm{w}$ imię niezależnego badania subiektywnej strony procesu historycznego, a więc w całkowitej izolacji od jego strukturalnych - technologicznych, ekonomicznych czy demograficznych - składników wydaje się, szczególnie w kontekście studiów nad postawami społecznymi, problematyczna. Spłyca, by nie powiedzieć, że wręcz uniemożliwia głębsze zrozumienie badanych zjawisk, nie wspominając już o tym, że wydaje się także przeciwskuteczna z punktu widzenia celów, które przyświecały Jasienicy w trakcie pracy nad książką o powstaniu w Wandei.

Zderzenie struktur społeczno-ekonomicznych z radykalnym wstrząsem politycznym, jakim niewątpliwie była rewolucja francuska, generując różne pola konfliktów, wpływało na świadomość i postawy zaangażowanych w nie ludzi, rodziło rozmaite antagonizmy i resentymenty, a także przekładało się na (zideologizowany) sposób opisu rzeczywistości. Tilly zwracał np. uwagę na fakt, że konstytucja cywilna kleru, sprowadzając księży do roli urzędników państwowych, nie tylko zmniejszyła ich dochody, ale również zwolniła ich z odpowiedzialności za wszelkiego rodzaju działalność charytatywną, mającą niebagatelne znaczenie w regionie, w którym biedni tkacze nieraz bardzo dotkliwie odczuwali powtarzające się kryzysy. Osoby zależne od takiej pomocy z obawami spoglądały na przerzucenie tych zadań na kierowaną przez burżuazję i operującą $\mathrm{w}$ ramach ścisłego budżetu nową administrację $e^{50}$. Widzimy, jak splecione były tu ze sobą utrata zupełnie wyjątkowej pozycji księży w wandejskich parafiach, położenie ekonomiczne określonej warstwy ludności oraz rodzące zrozumiałe obawy, a więc wpływające na nastawienia i postawy (czyli świadomość) reformy rewolucji. Analiza rzeczywistości społeczno-ekonomicznej umożliwiła również Tilly’emu postawienie tezy, że kajety skarg zwyczajnie nie wyrażały opinii chłopów, lecz były wypadkową relacji władzy istniejących $\mathrm{w}$ danym okręgu ${ }^{51}$.

${ }^{50}$ Ch. Tilly, dz. cyt., s. 234-235.

51 Tilly pisał np.: „the frequency of complaints about the franc-fief. The complaints were most common in the vicinity of Cholet, precisely where it was least likely that any peasant or artisan ever had to pay such a tax. I believe they expressed the views of bourgeois who already owned some property, and wished a great deal more were freely available"; tamże, s. 166. 
Wyrastające z odmiennych założeń ontologicznych różne nurty historiografii dwudziestowiecznej tym się właśnie charakteryzowały, że stosując właściwe sobie metody eksploracji przeszłości, oferowały poznanie niejednokrotnie przekraczające optykę narzucaną przez źródła historyczne. Źródłowe ekspresje świadomości poddawane były różnym, charakterystycznym dla określonych paradygmatów historycznych, procesom obiektywizującej je obróbki. Odwołajmy się do przykładu. Jak wiadomo, w opowieści o Morzu Śródziemnym Fernand Braudel jedną z najważniejszych ról powierzył przyrodzie. Zabieg ten przekładał się na sposób interpretacji tradycyjnie wykorzystywanych $\mathrm{w}$ historiografii źródeł. W rozdziale poświęconym zależności ludzkiego życia od rytmu przyrody historyk odniósł się do często bardzo ambitnych propozycji podbojów, jakie na wielu dworach różnej maści doradcy przedstawiali swoim mocodawcom. Wskazywał, że projekty te powstawały zwykle w miesiącach jesienno-zimowych, czyli w okresie, w którym $\mathrm{z}$ uwagi na przerwę $\mathrm{w}$ działaniach wojennych ich szybka realizacja była wykluczona. Zapominano o nich wraz z nadejściem pory, w której podjęcie operacji wojennych stawało się realną możliwością. Braudel ze słabo skrywanym sarkazmem komentował wysiłki tradycyjnej historiografii skrupulatnie rekonstruującej kolejne projekty rozmaitych rozbiorów ${ }^{52}$.

Wizja dziejów znajdująca swoją ontyczną podstawę w dialogu człowieka z przyrodą kryła w sobie, jak widzimy, poszerzenie pola krytyki źródłowych ekspresji świadomości. Spojrzenie w przeszłość programowo nieuwzględniające horyzontów poznawczych nowoczesnej historiografii ograniczało możliwość głębszej i bardziej krytycznej analizy przekazów mających odzwierciedlać tę bardziej literacką, subiektywną stronę procesu historycznego. Na ocenę świadectw pomstujących na upadek moralny i wzrost zbójnictwa na drogach wpływa przecież odkrycie, że stworzono je w okresie koincydencji wzrostu demograficznego oraz fali nieurodzajów.

Jasienicy zarzucano zwykle, że przeceniał wpływ, jaki na bieg dziejów wywierali główni bohaterowie jego książek - władcy i sternicy nawy państwowej. Twierdzono, że określające metodologiczny kształt jego prac „personalistyczne” 53 podejście nie oddawało sprawiedliwości kolektywnej, społecznej naturze dziejów ${ }^{54}$.

${ }^{52}$ F. Braudel, Morze Śródziemne i świat śródziemnomorski w epoce Filipa II, t. 1, tłum. G. Majcher, S. Meller, T. Mrówczyński, M. Ochab, Warszawa 2020, s. 236-239.

${ }_{53}$ Personalizm, o którym tu mowa, nie miał oczywiście nic wspólnego z filozofią Jacques’a Maritaina. W latach 60. pojęcie to wyrażało przekonanie o kluczowej roli, zwykle wybitnych, jednostek w dziejach.

${ }^{54}$ Do wniosku, że daleko idące uwolnienie władzy i polityki od podłoża społecznego jest nieuzasadnione, skłaniały uwagi poczynione przez Janusza Tazbira na marginesie Ostatniej $z$ rodu, pracy, którą Jasienica poświęcił Annie Jagiellonce. Tazbir podkreślał, że w pełni podziela przekonanie autora, iż znaczenie i autorytet „ostatniej z rodu” płynęło nie tyle z jej osobistych walorów, ile z przywiązania ogółu szlacheckiego do dynastii oraz szacunku, jaki ów ogół żywił dla pewnych reform ustrojowych. To jednak oznaczało - pisał Tazbir - że „nie tyle jednostka, ile jej kult odegrał twórczą i doniosłą rolę w dziejach”; tenże, Piękny arras z Jagiellonami, „Kultura” (Warszawa) 1965, nr 28, s. 8. 
W przypadku Rozważań zarzut ten tylko zyskiwał na sile. Baszkiewicz podkreślał, że Jasienica nie rozumiał dynamiki wydarzeń rewolucyjnych i w związku z tym mitologizował rolę, jaką w trakcie rewolucji odegrali jej liderzy. Nie dostrzegał, że znaleźli się oni „między arystokratyczną kontrrewolucją i ludową presją, jak między młotem i kowadłem”. Robespierre, rozwijał swoją myśl Baszkiewicz, zmieniał poglądy wraz z rozwojem rewolucji i ewolucją oczekiwań społecznych. „Nie bez wahań i oporów, bardzo powoli przyjmował program demokratycznej republiki, potem - już szybciej - program republiki socjalnej, egalitarnej, zdolnej zapewnić skromny dobrobyt każdemu”. Był to niewątpliwie program utopijny. „Czy wolno go jednak - pytał recenzent - uznać za przejaw oszalałego doktrynerstwa"? Wyrażał on wszak tęsknoty i aspiracje "potężnej siły społecznej, mas sankiulockich”. Spostrzeżenia dotyczące „Nieprzekupnego” wyrażały oczywiście ogólną prawidłowość związaną ze społecznym charakterem działań najwybitniejszych nawet jednostek. Wpisywały się więc w krytykę metodologicznego personalizmu. „Samowładztwo »mocnych« ludzi jest najczęściej nader względne. Wszechwładny cesarz Bizancjum, despotyczny król Francji i Nawarry w niemałym stopniu byli więźniami tradycji, rutyny rządzenia, przywileju elity. Wyniesiony przez wojsko cezar Rzymu, hiszpański czy iberoamerykański dyktator wojskowy - to często tylko niewolnik roszczeń i kaprysów swych pretorianów" 55 .

Widać więc, że Rozważania oraz dyskusja, jaką wywołały, wchodziły w zakres jednego z głównych pól problemowych określających charakter peerelowskiej historiografii - metodologicznego rozdarcia „między dogmatem a programem badawczym" ${ }^{\prime 2}$, między ideologicznym a teoretycznym wykorzystaniem marksizmu. W kontekst ten, obok komentarzy Mellera i Baszkiewicza, wpisywała się również krótka recenzja, jaką Rozważaniom poświęcił Aleksander Hall ${ }^{57}$ - autor wyróżniający się bezwarunkową aprobatą dla ich treści. W podsumowaniu swoich uwag stwierdzał, że „wizja rewolucji nakreślona przez Jasienicę jest nie tylko sugestywna, jest prawdziwa”. Ten epistemologiczny sukces miał swoje wyraźne metodologiczne zakorzenienie. Jak wskazywał Hall, Jasienica występując z krytyką polityki „podporządkowanej utopijnemu projektowi ideologicznemu”, zaprezentował zarazem alternatywną wobec marksistowskiej wizję rewolucji francuskiej. Publicysta „Przeglądu Katolickiego” pisał m.in.:

Obraz rewolucji francuskiej wyłaniający się z podręczników historii i licznych monografii poświęconych tej problematyce, z jakimi spotyka się polski czytelnik, jest jednostronny. Od prawie czterdziestu lat kształtują go przede wszystkie prace o wyraźnie marksistowskiej inspiracji. Są wśród nich dzieła wybitne, jak Rewolucja Francuska Alberta Mathieza, biografie Robespierre’a i Dantona

55 J. Baszkiewicz, Mitologia Wandei..., s. 12.

56 Nawiązuję tu rzecz jasna do znanej pracy: A. Zybertowicz, Między dogmatem a programem badawczym. Problemy stosowania teorii materializmu historycznego we wspólczesnej historiografii polskiej, Warszawa 1990.

57 A. Hall, O rewolucji inaczej, „Przegląd Katolicki” 1985, nr 46, s. 3. 
autorstwa Jana Baszkiewicza, Rewolucja francuska 1789-1794. Społeczeństwo obywatelskie Baszkiewicza i Stefana Mellera [...]. W zasadniczym zrębie interpretacyjnym wszystkie one są ze sobą zgodne. Rewolucja - wedle tej wizji - jest historycznie zdeterminowanym elementem procesu dziejowego..., jest tylko ogniwem w historii rozwoju społecznego, ale ogniwem niezbędnym. Przeprowadzona $\mathrm{w}$ interesie burżuazji, zadawała tym samym nieodwracalny cios porządkowi feudalnemu, sprzyjając $\mathrm{w}$ ten sposób postępowi społecznemu i torując drogę nowym siłom wstępującym na arenę dziejową. Najwyższą ocenę zyskiwały w tej perspektywie najbardziej radykalne nurty rewolucyjnych ugrupowań. Te właśnie, które zmierzały do konsekwentnej realizacji egalitarnego ideału, bezwzględnego wyplenienia wszelkich pozostałości starego porządku. Za apogeum rewolucji uznawano jakobińską dyktaturę, obaloną 9 termidora 1794 r. Różnice zdań dotyczyły jedynie oceny [...]. Terror rewolucyjny był uznawany za nieprzyjemny, ale niezbędny środek obrony zdobyczy rewolucyjnych i sprawne narzędzie eliminacji warstw reprezentujących reakcję feudalną. Stanowisko autora Rozważań o wojnie domowej jest całkowicie odmienne ${ }^{58}$.

Sens, jaki rewolucji francuskiej nadawał Jasienica, znacząco odbiegał zatem od sensu, jaki przysługiwał jej w obrębie historiozoficznego schematu teorii formacji społeczno-ekonomicznych. Zauważmy też, że walka o wyzwolenie życia z krępującego gorsetu szkodliwych ideologii, w jaką angażował się tu autor Polski Piastów, toczyła się niejako na dwóch frontach. Atak, jaki przypuścił na fanatyczne dążenie do budowy nowej rzeczywistości we Francji, zazębiał się z krytyką historycznej ideologii legitymizującej ustrój Polski Ludowej. Jeśli bowiem teoria formacji nie znajdowała zastosowania do wydarzeń mających stanowić jeden z jej podstawowych segmentów (rewolucja francuska), to automatycznie nie znajdowała takiego zastosowania również w odniesieniu do narodzin „ludowego” państwa, w którym żył Jasienica. Zaproponowana przez Halla metodologiczna kontekstualizacja Rozważań zupełnie jednak nie odpowiadała treści prac Baszkiewicza i Mellera. W żadnej z nich bowiem wspomniani autorzy nie odwoływali się do schematu teorii formacji. Recenzyjny komentarz, eksponujący znaczenie dzieła Jasienicy jako antymarksistowskiej alternatywy, wspierał się na zmitologizowanej ocenie historiografii Polski Ludowej ${ }^{59}$.

Baszkiewicz nie ograniczył się do omówienia kwestii związanej ze społeczną specyfiką zbuntowanego regionu oraz jej wpływem na wybuch zbrojnej kontrrewolucji. W obszernej recenzji wystąpił z krytyką niemal każdego aspektu recenzowanego dzieła. Wskazywał więc, że Jasienica mitologizował obraz społeczeństwa wandejskiego ${ }^{60}$ oraz wysłanych do stłumienia rebelii oddziałów republikańskich ${ }^{61}$,

58 Tamże, s. 3.

59 Pojawiające się kilkakrotnie w pracach Baszkiewicza sformułowanie „demokracja burżuazyjna” to za mało, by uznać, że odwołują się one do sztywnego historiozoficznego schematu.

60 W tym kontekście Baszkiewicz pisał np. tak: „Potrzebne mu [Jasienicy - A.M.] były argumenty o głębokim demokratyzmie wandejskich władz, więc twierdzi, że to chłopi wandejscy wybrali na generalissimusa chłopa Jacquesa Cathelineau. Wystarczy spojrzeć na często reprodukowany protokół tego wyboru, by stwierdzić, że dokonali go szlacheccy generałowie”; J. Baszkiewicz, Mitologia Wandei..., s. 10.

61 Z kolei w tym temacie czytamy m.in.: „Wśród personelu republikańskiego autor wprowadza wyraźny podział na złych polityków i dobrych zawodowców wojskowych. Stąd też polityk 
zniekształcał dzieje wojny ${ }^{62}$, jaką rewolucyjna Francja prowadziła z sąsiadami, a także żywił fałszywe wyobrażenia na temat ancien régime’u. Bezzasadne było również interpretowanie wydarzeń z $1793 \mathrm{r}$. w kategoriach swoistej prefiguracji hitlerowskiego ludobójstwa. „Z równym, a nawet większym powodzeniem - twierdził w tym kontekście - można by próbować innej identyfikacji: można by głosić, że hitlerowskim ludobójstwem avant la lettre były wyczyny katolików francuskich w latach 1562-1594, podczas długich i niewypowiedzianie okrutnych wojen religijnych" ${ }^{3}$. Wydaje się, że można wskazać dwa wzajemnie ze sobą powiązane powody, dla których Baszkiewicz w tak bezkompromisowy sposób podszedł do pracy Jasienicy. Po pierwsze można przypuszczać, że wybitny specjalista od dziejów Francji czuł się zobowiązany do zabrania głosu na temat książki, która swoje ideowe oblicze zyskała kosztem poważnego uszczerbku w korpusie istniejącej wiedzy historycznej. Po drugie zaś zobowiązanie to miało dla Baszkiewicza swoisty etyczny wymiar. W zakończeniu swoich uwag recenzent sformułował myśl następującą:

Można mi zapewne zarzucić, że polemizuję dość ostro z pisarzem, który już nie może replikować. Polemizuję jednak z tekstem, którego stylistyka jest niezwykle zbrutalizowana. Trudno nie pamiętać, jak Jasienica potraktował pisarzy i działaczy nieżyjących: ot, choćby Marata. „Zwłoki Marata usunięto wkrótce $\mathrm{z}$ Panteonu [...]. Francja zaczynała wymiatać nieczystości”. Jeśli ktoś powie mi teraz, że Marat zasłużył na to pogardliwe zdanie, ostre jak chlaśnięcie brzytwą, zapytam: czy oponent jest pewny, że dobrze zna pisma i działalność Marata? Bo trudno je ocenić po lekturze tekstu Jasienicy, który Maratowi poświęcił trzy krótkie ustępy, w tym dwa całkowicie błędne ${ }^{64}$.

Polemikę z recenzją Baszkiewicza podjął Włodzimierz Pawłowski. Próbując obronić Jasienicę przed częścią zarzutów, publicysta drugoobiegowego „Metrum” pisał m.in.: „Zawsze trzeba mieć w sobie tę odrobinę przychylności dla "przeciwnika«, by grać w tę grę, jaką on nam zaproponował; by stale mieć baczenie - jeśli nie stać nas na przyjęcie - na ten chód, jaki on sobie narzucił. I jeszcze - mieć w sobie tę szczyptę rycerskości, by nie szukać uporczywie potylicy »przeciwnika«;

\footnotetext{
Antoine Santerre jawi się nam jako srogi terrorysta (»wierny i zasłużony czciciel gilotyny«). Tak pisze Jasienica o człowieku, który okres terroru spędził w więzieniu i, dodajmy, na rewolucji nie zrobił majątku, lecz zrujnował się niemal doszczętnie. [...] Autor twierdzi, że gen. Jean Houchard został stracony, chociaż "pobił w polu Anglików i Austriaków«, a to pod zarzutem niewyzyskania wygranej bitwy, co zresztą ma być jakoby kwestią sporną. Otóż nie. Houchard wygrał bitwę pod Hondschoote dzięki brawurze i zimnej krwi komisarza Konwencji posła Sarthe’a Levasseura a więc "cywila«, "polityka« - który w przeciwieństwie do generała nie stracił ducha"; tamże.

62 „Jasienicy jest potrzebne uzasadnienie tezy, iż dyktaturę jakobińską motywowała zwykła żądza władzy grupy oszalałych doktrynerów. Twierdzi zatem, że wiosną 1794 roku zwycięstwo militarne Francji było zapewnione, zaś mit zagrożenia kraju podtrzymywany był fałszywie w interesie samowładztwa. To nie tak. Poważni badacze dziejów militarnych rewolucji zgodnie twierdzą, że zwycięstwo w kampanii letniej 1794 roku zostało osiągnięte z najwyższym trudem i wymagało największego wytężenia sił”; tamże.

63 Tamże, s. 14.

64 Tamże.
} 
w tej pozycji nie dość, że źle się "przeciwnika« widzi, w tej pozycji wypada się $\mathrm{z}$ roli polemisty, wpada się $\mathrm{w}$ rolę kata" ${ }^{35}$. Zostawiając na boku różne kwestie szczegółowe, główna linia argumentacji, jaką przyjął Pawłowski, sprowadzała się do podkreślenia, że, po pierwsze, perspektywa historyka naukowca zainteresowanego głównie ścisłą prezentacją określonego fragmentu przeszłości zupełnie nie odpowiadała szerszej historiozoficznej optyce, w jakiej bunt chłopski analizował Jasienica. Z tego punktu widzenia wizja autora Rozważań, właśnie dlatego, że dotyczyła historiozoficznego, a nie historycznego porządku, była niejako poza zasięgiem krytyki akademickiego historyka. „Strzelając z parteru przez sufit, trudno trafić kogoś, kto usadowił się kilka pięter wyżej”66. Pawłowski jednak, po drugie, nie ograniczał się do konstatacji wskazanej rozbieżności perspektyw. Zarzucał bowiem Baszkiewiczowi „udawaną wyniośle - naukową naiwność”. Ta udawana naiwność była sposobem na uniknięcie „otwartego sporu z wizją historiozoficzną". Wyliczając różne faktograficzne błędy, Baszkiewicz „strzelał zza węgła”. Zakładał maskę historyka naukowca, by niejako ukryć swoje ideologiczne preferencje. Te zaś, można mniemać, wiązały się z lewicową aprobatą dla rewolucji, niepodzielaną oczywiście przez Jasienicę. Pawłowski nie odbierał badaczowi prawa do głoszenia swoich przekonań. „Nie mam - pisał - Baszkiewiczowi za złe, że jest rewolucji francuskiej aż tak życzliwy" ${ }^{67}$. Krytykował jedynie jego zdaniem nieuzasadnioną i niewolną od ideologicznych naleciałości strategię piętnowania niedoskonałości dzieła Jasienicy. Nie sposób jednak nie zauważyć, że historiozoficzna klasyfikacja Rozważań kolidowała z fragmentami zawierającymi krytykę idei konieczności historycznej oraz negację teleologicznej natury dziejów. W tym kontekście Jasienica manifestował podzielaną przez większość akademickich historyków niechęć do historiozoficznych spekulacji.

Z kolei sprzeciw wobec zwalniania wybitnych filozofów oświecenia z odpowiedzialności za terror i przemoc, do której doszło w trakcie rewolucji, zgłosił autor drugoobiegowego „Ogniwa”, występujący pod niepozostawiającym wątpliwości co do jego ideologicznych preferencji pseudonimem Erazm Spasowicz. Recenzent stwierdzał, że Rousseau ponosi „niewspółmiernie większą winę” za zło rewolucji aniżeli Robespierre. Przekonanie to argumentował w następujący sposób:

Autor umowy społecznej głoszący, iż „wola ogółu” jest zawsze słuszna, lecz nie zawsze umie się rozpoznać, wprowadza tym samym masy na scenę historii, by posłużyć się nimi jako taranem przeciw Królowi, Kościołowi i Tradycji. Rezerwując dla ludu prawo nieomylności, dla siebie - przywilej przesądzania o tym co nieomylne, wyłączył Rousseau poza nawias jednostki nie godzące się z każdorazową wolą ogółu. To przyszli wrogowie ludu. Aż się prosiło o Robespierre’a. Nic dziwnego, że się pojawit ${ }^{68}$.

${ }^{65}$ P. Gazda (właść. W. Pawłowski), Pochwała umiaru..., s. 55.

66 Tamże, s. 56.

67 Tamże.

${ }^{68}$ E. Spasowicz, Rewolucja, odpowiedzialność, polityka, „Ogniwo” 1988, nr 32, s. 8. 
„Obłąkany racjonalizm filozofów” nie padłby na tak podatny społecznie grunt, gdyby nie „tyrania pragmatyki urzędniczej”. Masy dały się uwieść zgubnym ideom wskutek „zurzędniczenia” i „etatyzacji przedrewolucyjnej Francji”. Wśród przewin dawnego ustroju recenzent wymieniał samowolę i nadużycia biurokracji, zniewolenie stanu chłopskiego, ujarzmienie mieszczaństwa, spoliację podatkową oraz „kwitnącą na dworze i za przyczyną dworu pogardę dla etosu przedsiębiorczości prywatnej"69. Na elitach społecznych, które nigdy nie powinny naginać swoich zasad do woli ludu, spoczywało ważne zadanie zapobiegania wszelkim rewolucjom. Te bowiem nigdy do niczego dobrego nie prowadziły.

\section{IV}

Recenzenci zasadnie wskazywali na oczywiste odniesienia Rozważań do współczesności. Ostatnie dzieło Jasienicy było niewątpliwie krytycznym komentarzem do rzeczywistości, $\mathrm{w}$ jakiej powstało. $\mathrm{W}$ tej prezentystycznej warstwie można je analizować zgodnie $\mathrm{z}$ metodologicznymi postulatami formułowanymi przez Quentina Skinnera w tekstach poświęconych interpretacji dzieł z zakresu filozofii politycznej ${ }^{70}$. Wysiłek badacza, głosi zalecenie angielskiego historyka, skierowany być musi na wydobycie illokucyjnej mocy interpretowanych wypowiedzi. Moc ta zaś staje się jasna dopiero $\mathrm{w}$ zestawieniu $\mathrm{z}$ ideologicznym kontekstem, $\mathrm{w}$ jakim wypowiedzi te powstają. Uchwycenie relacji między ich treścią a owym kontekstem wymaga z kolei wyjścia poza tekst, którego są częścią. Oczywiście polityczno-ideologiczny kontekst, w jakim powstały Rozważania, jest z uwagi na niewielki chronologiczny dystans, jaki dzieli nas od epoki PRL i na wciąż żywą pamięć oraz szeroką wiedzę dotyczącą peerelowskiej rzeczywistości, jasny i oczywisty. Określały go monopartyjne rządy odnajdujące swoją historyczną legitymację w teorii formacji społeczno-ekonomicznych. Ideowy sens Rozważań wiązał się z nawoływaniem do odrzucenia zarówno millenarystycznej, komunistycznej utopii, jak i ustroju, który legitymizowała - implementacja idei trójpodziału władzy, o którą apelował Jasienica, była raczej nie do pomyślenia na gruncie „demokracji ludowej”, wymagała jej zniesienia. Wiążąc pojęcie „konieczności historycznej” z doktrynerskim uzasadnieniem krwawych ekscesów, do jakich dochodziło w trakcie rewolucji, Jasienica niejako „kompromitował” historiozoficzny schemat

69 Tamże.

70 Poza najbardziej znanym tekstem Skinnera Meaning and Understanding in the History of Ideas, „History and Theory” 1969, nr 1, s. 3-53, warto tu wymienić jeszcze inne jego artykuły: Motives, Intentions and Interpretations of Texts, w: Meaning and Context. Quentin Skinner and His Critics, red. J. Tully, Princeton 1988, s. 68-79; Some Problems in the Analysis of Political Thought and Action, w: tamże, s. 97-119; Social Meaning and the Explanation of Social Action, w: Philosophy, Politics and Society. Fourth Series, red. P. Laslett, W.G. Runciman, Q. Skinner, New York 1972, s. $112-138$. 
stanowiący historyczno-ideologiczną legitymację władzy „ludowej” w Polsce. Teoria formacji przedstawiała wszak konieczny scenariusz dziejowego rozwoju, który wraz z nastaniem Polski Ludowej znalazł, twierdzono, swoje ostateczne spełnienie. Aksjologicznie pozytywna fuzja dziejowej konieczności z ludowym wyzwoleniem zastąpiona została aksjologicznie negatywną asocjacją idei historycznej konieczności z polityką terroru gwałcącą fundamentalne wartości oświecenia. Rozważania były więc również rodzajem politycznej agitacji, apelem o zmianę sposobu organizacji życia zbiorowego Polaków, nawoływaniem do ponownego włączenia się w główny nurt dziejów Zachodu.

Ideologiczny cel Rozważań osiągnięty jednak został z poważnym, jak się wydaje, naruszeniem istniejącego korpusu wiedzy historycznej ${ }^{71}$ oraz za cenę anachronicznej, by nie rzec ahistorycznej, wizji rewolucyjnej ideologii. Wśród recenzentów, jak widzieliśmy, nie było zgody co do tego, czym w istocie były Rozważania i w jakich kategoriach należy je rozpatrywać. Ich naturę próbowano uchwycić, stosując takie określenia jak: „rozprawa historiozoficzna”, „traktat moralny” czy też „wypowiedź ideologiczna”. Odnosi się wrażenie, że ta klasyfikacyjna ekwilibrystyka służyła m.in. ochronie dzieła Jasienicy przed krytyką opierającą się na zwykłych kryteriach epistemicznych i warsztatowych. Merytoryczne niedociągnięcia starano się jakoś oddzielić od ideowego przesłania, które podzielała większość recenzentów (autorzy publikacji, które ukazały się w drugim obiegu, a także Hall i Meller). Recepcja Rozważań była więc zapośredniczona ideowymi preferencjami oceniających ją autorów.

Temat rewolucyjnej ideologii (czy szerzej rewolucyjnych ideologii) w interesującym świetle stawiał spór między metodologicznym personalizmem, znajdującym swój wyraz w kolejnych pracach Jasienicy, a metodologicznym kolektywizmem, do którego nawiązywała większość jego akademickich krytyków. Wychodząc z marksistowskich założeń, Baszkiewicz, jak widzieliśmy, wskazywał, że poglądy liderów francuskiego przewrotu wyrażały interesy określonych klas społecznych. W ujęciu tym ideologia była jedynie epifenomenem relacji wiążącej poszczególne sektory społeczne z rzeczywistością materialną i nie należało jej „indywidualizować”.

${ }^{71} \mathrm{~W}$ tym kontekście warto zacytować jeszcze jeden fragment $\mathrm{z}$ recenzji Baszkiewicza: „Jego argumentacja posługuje się chętnie metodą swoistej anachronizacji: wyjaśnia insurekcję wandejską przyczynami, które już ustały albo jeszcze nie zaczęły działać. Kilkakrotnie autor powraca do reformy Kościoła i systemu cenzusów. Oburza się, że wybór proboszczów oddano w ręce »bogaczy«, często niewierzących lub protestantów, odsuwając od elekcji chłopów. To nieporozumienie. Po pierwsze, cenzusy nie odgradzały od wyborów chłopów-posiadaczy; uderzały przede wszystkim w sankiulotów. Po drugie, w momencie wybuchu powstania cenzusy nie istniały już od wielu miesięcy: system wyborów cenzusowych załamał się razem z monarchią, latem 1792 roku. Zapalnym problemem w Wandei - i nie tylko tam - była wtedy kwestia przysięgi politycznej lojalności, wymaganej od kleru, a nie kwestia obsadzania stanowisk duchownych w parafiach"; J. Baszkiewicz, Mitologia Wandei..., s. 13-14. 
Z kolei „personalistyczne” podejście Jasienicy nosiło wyraźne znamiona paradygmatycznej niewydolności. Poruszając kwestie ideologiczne, autor Rozważań wikłał się w oczywiste sprzeczności. Raz sugerował, że „monarchia francuska wyrosła z tysiącletniej praktyki”, a „odskocznią dla Robespierre’a i jemu podobnych była teoria, doktryna"72, by za chwilę całkiem autorytatywnie stwierdzać, że „dzieje ustrojów totalnych dostarczyły już tak obfitego materiału, że... ma się $\mathrm{w}$ związku $\mathrm{z}$ tym prawo pobieżnie traktować ideologię" ${ }^{73}$. $\mathrm{Z}$ jednej strony próbował przekonać czytelnika, że za zło, jakie wyrządzono w trakcie rewolucji, odpowiadała garstka doktrynerów. Zarazem jednak powiadał, że Condorcet nie na darmo nazwał „Konstytuantę zgromadzeniem tysiąca dwustu metafizyków”74. Tysiąc dwustu członków ciała debatującego nad ustanowieniem nowego ustroju to jednak nie to samo, co garstka ideologów.

Ciekawe, że „personalistyczne” ujęcie ideologii okazało się sprzeczne z wnioskami badaczy, którzy podobnie jak Jasienica odrzucali redukcjonistyczne interpretacje świata idei. Jak wskazywał np. William H. Sewell, społeczeństwa funkcjonują zawsze $\mathrm{w}$ ramach określonego porządku ideologicznego, tworzącego ponadindywidualną, anonimową i do pewnego przynajmniej stopnia autonomiczną strukturę. Rewolucja przyniosła oczywiście istotne zmiany w zakresie obowiązującej ideologii. Koncepcje prawa naturalnego, suwerenności, autonomii, rozumu, wolności i równości itd. wyparły (w ostatnich dekadach ancien régime’u oba porządki współistniały ze sobą) korporacyjną wizję świata, w której sprawujący władzę z Bożej łaski monarcha nadzoruje i scala różne ciała funkcjonujące w obrębie różnych reguł i przywilejów. Krytykowana przez Jasienicę konstytucja cywilna kleru nie była wybrykiem garstki doktrynerów. Jej uchwalenie wpisane było $\mathrm{w}$ ideologiczną logikę francuskiego przewrotu. Zobowiązania duchowieństwa wobec papieża i Watykanu kłóciły się z ideą suwerenności narodu - część obywateli deklarowała lojalność wobec instytucji znajdującej się poza kontrolą całej suwerennej wspólnoty. Przysięga na wierność konstytucji miała usunąć tę niekonsekwencję. Jej egzekwowanie doprowadziło jednak do niezwykłej politycznej polaryzacji społeczeństwa francuskiego i do wzrostu nastrojów radykalnych. Ustawa z 12 lipca 1790 r. była więc niewątpliwie jedną z przyczyn wybuchu powstania w Wandei. Nie była jednak „wynaturzeniem” rewolucji. Stanowiła, przynajmniej $\mathrm{z}$ ideologicznego punktu widzenia, część jej istoty ${ }^{75}$.

72 P. Jasienica, Rozważania..., s. 108.

73 Tamże, s. 110.

74 Tamże, s. 47.

75 W.H. Sewell Jr., Ideologies and Social Revolutions. Reflections on the French Case, „The Journal of Modern History" 1985, nr 1, s. 80. Interesujące uwagi na temat rewolucyjnej ideologii znaleźć można również w klasycznej już pracy François Fureta, Penser la Révolution française (korzystałem $\mathrm{z}$ ang. tłum.: Interpreting the French Revolution, Cambridge 2001) oraz w: L.A. Hunt, Politics, Culture and Class in the French Revolution, Berkeley 2004. 
Oczywiście Jasienica nie mógł znać literatury, którą tu przywołuję. Warto jednak było zestawić jego „personalizm” z późniejszymi studiami poświęconymi ideologicznym aspektom rewolucji, wskazując, że stanowisko metodologiczne, jakie reprezentował, stawało się problematyczne nie tylko w obrębie interpretacji marksistowskich.

Warto wreszcie spojrzeć na Rozważania z dzisiejszej perspektywy. Jasienica przekonywał o naturalnej społecznej skłonności do akceptacji idei i ideałów oświecenia. Na drodze do budowy ustroju opierającego się na podziale władz stawali zwykle nieliczni. Niewykluczone, że ten wyidealizowany obraz społeczeństwa odpowiadał wyzwaniom epoki PRL. Z pewnością też pogłębiał wiarę w powszechne poparcie dla liberalno-oświeceniowego projektu. Jednak nadzieje na jego automatyczną realizację okazały się złudzeniem. Znacząca zgoda na sojusz tronu i ołtarza, w której można widzieć jedno ze źródeł dzisiejszego kryzysu konstytucyjnego porządku politycznego, burzy mit naturalnej społecznej gotowości do obrony liberalnych wartości Zachodu i pozwala wątpić w spontaniczną trwałość ustroju, w którym władza, pozostając w zgodzie z demokratyczną aksjologią, działa wyłącznie w ramach i na gruncie istniejącego prawa. Trudno nie zadać w tej sytuacji pytania, czy liberalno-demokratyczny optymizm, do którego powstania przyczynił się swoim dziełem Jasienica, we współczesnej Polsce nie obrócił się przeciwko jego własnym poglądom i wartościom? Czy Jasienica - niczym Paul z Kunderowskiej Nieśmiertelności - nie okazał się „błyskotliwym sprzymierzeńcem własnych grabarzy?"76 Historia po raz kolejny pokazała swą ironiczną twarz.

\section{Bibliografia}

B. Baczko, Poglady społeczno-polityczne i filozoficzne Towarzystwa Demokratycznego Polskiego, Warszawa 1955

J. Baszkiewicz, Mitologia Wandei, „Polityka” 1983, nr 44, s. 1, 10-14

J. Baszkiewicz, S. Meller, Rewolucja francuska 1789-1794. Społeczeństwo obywatelskie, Warszawa 1983

P. Bois, Paysans de L'Ouest, Paris 1971

F. Furet, Interpreting the French Revolution, Cambridge 2001

P. Gazda (właść. W. Pawłowski), Pochwała umiaru, „Metrum” 1988, nr 4, s. 43-57

A. Gieysztor, Pawet Jasienica. Historyk polski, „Tygodnik Powszechny” 1971, nr 34, s. 7

A. Hall, O rewolucji inaczej, „Przegląd Katolicki” 1985, nr 46, s. 3

L.A. Hunt, Politics, Culture and Class in the French Revolution, Berkeley 2004

P. Jasienica, Polska anarchia, Warszawa 1988

P. Jasienica, Rozważania o wojnie domowej, Warszawa 2007

P. Jasienica, Rzeczpospolita Obojga Narodów, t. 1: Srebrny Wiek, Warszawa 1967

P. Jasienica, Rzeczpospolita Obojga Narodów, t. 3: Dzieje agonii, Warszawa 1972

P. Jasienica, Tylko o historii, Warszawa 1962

${ }^{76}$ M. Kundera, Nieśmiertelność, tłum. M. Bieńczyk, Warszawa 2002, s. 137-142. 
K. Koźniewski, Różnica zdań, „Życie Warszawy” 7-8 XII 1985

J. Lipski, Pisma polityczne, wybór i oprac. Ł. Garbal, Warszawa 2011

S. Meller, Pożegnanie z rewolucja, Chotomów 1991

S. Meller, Rozważania o „Rozważaniach o wojnie domowej”, „Znak” 1986, nr 6, s. 128-137

A. Mękarski, Między historiozofia a polityką. Historiografia Polski Ludowej w opiniach i komentarzach historyków i publicystów emigracyjnych 1945-1989, Warszawa 2011

A. Mękarski, Między mitem a polityczną racjonalnością. Myśl historyczna Pawła Jasienicy i jej recepcja w dobie Polski Ludowej, „Kwartalnik Historyczny” 2013, nr 1, s. 55-97

O historii po heretycku. Z Pawłem Jasienica w imieniu „Polityki” rozmawia Krystyna Nastulanka, „Polityka” 1960, nr 48, s. 7

Ostatnia ksiażka, ostatnie słowo, „Kierunek” 1986, nr 1

S. Salmonowicz, Wandea. Anatomia ludowej kontrrewolucji, „Kwartalnik Historyczny” 1967, nr 4, s. 945-962

W.H. Sewell Jr., Ideologies and Social Revolutions. Reflections on the French Case, „The Journal of Modern History" 1985, nr 1, s. 57-85

Q. Skinner, Meaning and Understanding in the History of Ideas, „History and Theory” 1969, nr 1, s. 3-53

Q. Skinner, Motives, Intentions and Interpretations of Texts, w: Meaning and Context. Quentin Skinner and His Critics, red. J. Tully, Princeton 1988, s. 68-79

Q. Skinner, Social Meaning and the Explanation of Social Action, w: Philosophy, Politics and Society. Fourth Series, red. P. Laslett, W.G. Runciman, Q. Skinner, New York 1972, s. 112-138

Q. Skinner, Some Problems in the Analysis of Political Thought and Action, w: Meaning and Context. Quentin Skinner and His Critics, red. J. Tully, Princeton 1988, s. 97-119

E. Spasowicz, Rewolucja, odpowiedzialność, polityka, „Ogniwo” 1988, nr 32, s. 7-9

R. Stobiecki, Stalinowska mitologizacja idei postępu, w: Historia, mity, interpretacje, red. A. Barszczewska-Krupa, Łódź 1996, s. 139-147

Świat według Mellera. Życie i historia. Ku wolności. Ze Stefanem Mellerem rozmawia Michał Komar, Warszawa 2008

J. Tazbir, Piękny arras z Jagiellonami, „Kultura” (Warszawa) 1965, nr 28

J. Tazbir, Wizja Polski Pawła Jasienicy, „Nowe Książki” 1984, nr 2

Ch. Tilly, The Vendée, Harvard 1976

A. Walicki, Marksizm i skok do królestwa wolności. Dzieje komunistycznej utopii, Warszawa 1996

A. Zybertowicz, Między dogmatem a programem badawczym. Problemy stosowania teorii materializmu historycznego we wspótczesnej historiografii polskiej, Warszawa 1990

J. Żmigrodzki, Sąd nad Mierosławskim, „Polemiki” 1966, nr 5, s. 43-62

\section{Ideology and Method in Rozważania o wojnie domowej (Reflections on the Civil War) by Pawel Jasienica. Regarding the work and its reception}

This article sets itself two tasks. First, it attempts to offer an insight into Rozważania o wojnie domowej (Reflections on the Civil War), the last book by Paweł Jasienica, an essayist and acclaimed history writer known mainly for his books on the history of Poland. Second, it also investigates the reception of the work it interprets. In executing the first task, the author focuses mainly on extracting the critique of the communist ideology which Jasienica included, in some veiled way, in his account of the main topic to which his last book is devoted - the Vendée rebellion of 1793. Throughout the text, the reader is made to believe that the leading revolutionaries whom Jasienica 
considered responsible for the atrocities committed in the course of suppressing the Vendée rebellion were guided by the idea of historical necessity. However, the concept of historical necessity, argues the author, should be viewed as pertaining to the ideology not of the French revolutionaries but of the communists in Poland. While the concept played no part in the former's efforts to justify the overthrow of the old regime, it was used by the latter to legitimise their rule in Poland. By associating the concept of historical necessity with the Vendée massacres, Jasienica sought to "discredit" the communist ideology on which the political system in Poland was based. In other words, he used his account of one of the episodes of the French revolution to criticise the PRL's political system, arguing, one should add, in favour of replacing it with liberal democracy.

Analysis also shows that the reception of Jasienica's work was significantly mediated by the ideological preferences of its reviewers. Some of them, clearly sharing Jasienica's beliefs, claimed that Rozważania should not be classified as a typical historical monograph but should rather be treated as a moral treaty or a historiosophical treatise. This terminological juggling was designed to deflect the criticism which the work received as an ordinary historical study suffering, as one reviewer specializing in the history of the French Revolution showed, from a significant number of defects and inaccuracies.

Artur Mękarski - dr, adiunkt w Instytucie Historii Uniwersytetu Śląskiego. Zainteresowania naukowe: historia historiografii Polski Ludowej, polska historiografia emigracyjna po 1945 r. oraz angielska szkoła historii idei. Autor: Między historiozofia a polityką. Historiografia Polski Ludowej w opiniach i komentarzach historyków i publicystów emigracyjnych 1945-1989, Warszawa 2011. E-mail: amekarski47@wp.pl 